\title{
Gehechtheid en internaliserend en externaliserend probleemgedrag bij adolescenten
}

Kirsten L. Buist, Maja Deković, Wim Meeus en Marcel A.G. van Aken

Kind en Adolescent, 25 (2004), p. 132-149

\section{Samenvatting}

Het doel van dit onderzoek was om de relatie tussen kwaliteit van gehechtheid aan ouders en internaliserend en externaliserend probleemgedrag van adolescenten na te gaan. In dit longitudinaal onderzoek, bestaande uit drie meetmomenten met steeds een jaar tussentijd, verstrekten 288 adolescenten (gemiddeld 13,5 jaar tijdens de eerste meetronde) informatie over de kwaliteit van de gehechtheidsrelatie met hun ouders en over hun eigen probleemgedrag. Zowel de kwaliteit van de gehechtheid als beide indicatoren van probleemgedrag bleven stabiel. Negatieve wederkerige effecten werden gevonden tussen kwaliteit van gehechtheid en beide soorten probleemgedrag. Adolescenten met een hogere kwaliteit van gehechtheid aan ouders vertoonden een jaar later minder internaliserend en externaliserend probleemgedrag, en andersom.

\section{Inhoud}

- $\quad$ De wederkerige relatie tussen gehechtheid en internaliserend en externaliserend probleemgedrag bij adolescenten

- $\quad$ Methode

- $\quad$ Resultaten

- $\quad \underline{\text { Discussie }}$

- $\quad \underline{\text { Literatuur }}$

\section{De wederkerige relatie tussen gehechtheid en internaliserend en externaliserend probleemgedrag bij adolescenten}

De adolescentie wordt in het algemeen beschouwd als een periode waarin veel veranderingen plaatsvinden in het leven van kinderen en gezinnen met kinderen. Alhoewel deze leeftijdsfase traditioneel werd beschouwd als een periode van storm en stress blijkt dit meer uitzondering dan regel (Coleman, 1993; Meeus, 1992; Steinberg, 2001). Desondanks worden adolescenten geconfronteerd met een aantal uitdagingen. Het succes waarmee ze deze hordes nemen kan van invloed zijn op hun verdere ontwikkeling. Eén van de belangrijkste uitdagingen is het hervinden van een positie binnen het gezin, die aansluit bij de nieuwe mogelijkheden, vrijheden en verantwoordelijkheden van de adolescent (Laible, Carlo, \& Rafaelli, 2000). Een invloedrijke factor bij het al dan niet succesvol voltooien van deze taak is de kwaliteit van de gehechtheid aan de ouders.

De term gehechtheid werd oorspronkelijk gebruikt voor de affectieve band tussen baby's en hun verzorgers, maar door de jaren heen heeft het gebruik van deze beperkte definitie zich uitgebreid naar andere ontwikkelingsperiodes en andere gehechtheidsfiguren, en wordt gehechtheid verondersteld tijdens de hele levensloop van invloed te zijn op het functioneren van de mens (Bowlby, 1982; Lopez \& Gover, 1993). Een algemene definitie van gehechtheid is: een langdurige, affectieve band van een aanzienlijke intensiteit.

Volgens de gehechtheidstheorie vormen kinderen tijdens de vroege kindertijd een intern werkmodel van gehechtheid, gebaseerd op gehechtheidsgerelateerde ervaringen met verschillende gehechtheidsfiguren (Bowlby, 1982; Colin, 1996). Deze interne werkmodellen bestaan uit twee aparte maar verwante componenten: 1. een model van het zelf, dat aangeeft in hoeverre iemand zichzelf de moeite waard vindt; en 2. een model van de sociale wereld, dat aangeeft in hoeverre iemand de (belangrijke) mensen om zich heen ziet als betrouwbaar (Lopez \& Brennan, 2000).

Naast deze algemene interne werkmodellen van gehechtheid, blijven de specifieke gehechtheidsrelaties en affectieve banden ook invloedrijk tijdens de levensloop. De invloed van deze affectieve banden is vooral groot in tijden van stress en belangrijke veranderingen (Colin, 1996; Lopez \& Brennan, 2000). Vanwege de aanwezigheid van een groot aantal mogelijk stressvolle veranderingen tijdens de adolescentie zijn gehechtheidsrelaties juist tijdens deze periode erg relevant. In dit onderzoek wordt met de kwaliteit van de gehechtheid aan vader of moeder steeds deze relaties met specifieke gehechtheidsfiguren bedoeld, en niet het algemene werkmodel van gehechtheid.

De relevantie van de kwaliteit van de gehechtheid aan ouders tijdens de adolescentie is gedocumenteerd in een grote hoeveelheid onderzoeken waarin de kwaliteit van de gehechtheid gerelateerd wordt aan indicatoren van psychosociaal functioneren tijdens de adolescentie, zoals identiteitsontwikkeling (Lapsley, Rice, \& Fitzgerald, 1990; Samuolis, Layburn, \& Schiaffino, 2001), en welbevinden (Barnas, Pollina, \& Cummings, 1991; Raja, McGee \& Stanton, 1992; Armsden \& Greenberg, 1987). Daarnaast lijkt de kwaliteit van de gehechtheid ook een remmend 
effect te hebben op deviante ontwikkeling, zoals probleemgedrag in het algemeen (Leadbeater, Kuperminc, Blatt, \& Hertzog, 1999).

In veel onderzoeken vatten onderzoekers probleemgedrag op als een algemeen construct, zonder een duidelijk onderscheid te maken tussen twee verschillende soorten probleemgedrag: internaliserend (depressie en angst) en externaliserend (agressie en delinquentie) probleemgedrag. De adolescentie is de ontwikkelingsperiode waarin zowel internaliserend als externaliserend probleemgedrag een (tijdelijke) toename in prevalentie lijkt te laten zien (Moffitt, 1993; Roberts, Andrews, Lewinsohn, \& Hops, 1990). Onderzoeken waarin wél onderscheid werd gemaakt tussen deze twee soorten probleemgedrag concentreerden zich óf op internaliserend, óf op externaliserend probleemgedrag waardoor het onduidelijk blijt of de beïnvloedingspatronen tussen de kwaliteit van de gehechtheid en deze twee soorten probleemgedrag vergelijkbaar zijn of juist van elkaar verschillen. In het huidige onderzoek gaan we deze kwestie bestuderen.

Als we uitgaan van de aanname dat een lage kwaliteit van gehechtheid samenhangt met een negatieve zelfperceptie, ligt het voor de hand te verwachten dat er een negatieve relatie bestaat tussen kwaliteit van gehechtheid en internaliserend probleemgedrag zoals depressie, angst en teruggetrokken gedrag (Allen, Moore, Kuperminc, \& Bell, 1998). Empirische onderzoeken hebben inderdaad aangetoond dat adolescenten met een lage kwaliteit van gehechtheid aan hun ouders een hogere mate van depressie (Laible e.a., 2000; Raja, McGee, \& Stanton, 1992) en angst (Raja e.a., 1992) hebben.

Vanuit theoretisch oogpunt zouden we ook een negatief verband verwachten tussen ouder-kindrelaties en externaliserend probleemgedrag bij adolescenten zoals delinquentie en agressie. Een adolescent met een lage kwaliteit van gehechtheid zou zijn/haar sociale omgeving als onbetrouwbaar zien, waardoor hij of zij tegen deze vijandige omgeving in opstand kan komen. In een aantal empirische onderzoeken is een relatie aangetoond tussen ouder-kindrelaties en externaliserend probleemgedrag bij adolescenten. Hoge kwaliteit van gehechtheid is gekoppeld aan minder of minder ernstig delinquent gedrag (Allen e.a., 1998), en minder agressief gedrag (Laible e.a., 2000; Marcus \& Betzer, 1996). Andersom geldt dat adolescenten die een lage kwaliteit van gehechtheid aan hun ouders rapporteren meer gedragsproblemen laten zien (Raja e.a., 1992).

Alhoewel eerdergenoemde onderzoeken hebben aangetoond dat gehechtheid tijdens de adolescentie samenhangt met psychosociaal (dis)functioneren zijn deze onderzoeken beperkt in de mogelijkheid om causale relaties vast te stellen. De meeste van de hiervoor genoemde onderzoeken zijn namelijk cross-sectioneel van aard. Verbanden tussen de kwaliteit van de gehechtheid en het internaliserende of externaliserende probleemgedrag zijn in deze onderzoeken geïnterpreteerd als een invloed van de kwaliteit van de gehechtheid op psychosociaal functioneren.

In een cross-sectionele opzet is het echter niet mogelijk om deze veronderstelde richting van effecten te toetsen. Alhoewel deze interpretatie best juist kan zijn, is het ook waarschijnlijk dat de kwaliteit van de gehechtheid wordt beïnvloed door psychosociaal functioneren van de adolescent (Laible e.a., 2000). Het zou best zo kunnen zijn dat de richting van beïnvloeding eveneens de andere kant op wijst: internaliserend en externaliserend gedrag beïnvloeden de kwaliteit van de gehechtheid.

Er zijn enkele redenen om beide richtingen te verwachten. Internaliserende problemen zouden de kwaliteit van gehechtheidsrelaties van adolescenten aan hun ouders kunnen beïnvloeden. Een angstige en/of depressieve adolescent heeft de neiging om zich terug te trekken uit relaties, waardoor er een vervreemding tussen kind en ouder kan ontstaan, wat een lagere gepercipieerde kwaliteit van gehechtheid tot gevolg zou kunnen hebben. Ook externaliserend probleemgedrag kan de gezinsharmonie erg verstoren en de relatie tussen adolescent en ouders verslechteren (Barnes \& Farrell, 1992). Als de adolescent bijvoorbeeld gestraft wordt voor zijn of haar vergrijpen is het waarschijnlijk dat de ouders bij de adolescent in een behoorlijk negatief daglicht komen te staan, als minder sensitief en responsief worden gezien, en de adolescent ook een lagere kwaliteit van gehechtheid aan de ouders waarneemt.

Hoewel in sommige onderzoeken de wederkerige relatie tussen het psychosociaal functioneren en de kwaliteit van de gehechtheid van adolescenten aan hun ouders wel wordt verondersteld, zijn ons geen onderzoeken bekend die deze veronderstelling uitdrukkelijk hebben getoetst. Om deze reden gaan we in het huidige onderzoek zowel de veronderstelling toetsen dat de kwaliteit van de gehechtheid probleemgedrag beïnvloedt als de veronderstelling dat probleemgedrag van invloed is op de kwaliteit van de gehechtheid.

Samenvattend is het doel van het huidige onderzoek: het op basis van longitudinale gegevens onderzoeken van de wederkerige relatie tussen de kwaliteit van de gehechtheid van adolescenten aan hun ouders enerzijds en probleemgedrag anderzijds. Daarnaast gaan we bekijken of deze wederkerige relatie dezelfde is voor de twee soorten probleemgedrag: internaliserend en externaliserend.

\section{Methode}

\section{Procedure en respondenten}

De wervingsprocedure bestond uit twee fasen. In de eerste fase zijn 23 voor Nederland representatieve gemeenten gevraagd om een lijst te leveren met alle gezinnen met ten minste twee kinderen in de leeftijd van elf tot vijftien jaar en twee ouders die allemaal op hetzelfde adres woonden. Deze gemeenten waren verspreid over heel Nederland. Er deden zowel gemeenten mee met een lage als met een gemiddelde of hoge urbanisatiegraad. Het benodigde aantal gezinnen per gemeente was afhankelijk van de grootte van de gemeente: hoe groter de gemeente, hoe groter het aantal gezinnen. Als er meer gezinnen in aanmerking kwamen dan nodig was, gezien de grootte van de gemeente, selecteerden gemeenteambtenaren willekeurig het benodigde aantal gezinnen uit de lijst. 
In de tweede fase van de wervingsprocedure kregen 649 kandidaat-gezinnen een introductiebrief toegestuurd waarin ze werden geïnformeerd over het project. $\mathrm{Na}$ een paar dagen werd per telefoon contact opgenomen met deze gezinnen. Tijdens dit gesprek werd gecontroleerd of het gezin aan de voorwaarden voldeed: ten minste twee kinderen tussen de elf en vijftien jaar, en beide ouders wonend op hetzelfde adres. Voor $11,1 \%(N=72)$ bleek dit niet het geval te zijn te zijn. De resterende gezinnen werden uitgenodigd om mee te doen aan het onderzoek. Van de 577 kandidaat-gezinnen wilden er uiteindelijk $288(49,9 \%)$ meedoen. De gezinnen die niet wilden meedoen gaven als voornaamste redenen dat ze niet geïnteresseerd waren in het thema van het onderzoek $(92 ; 31,8 \%)$ of dat één van de vier gezinsleden niet mee wilde doen $(72 ; 24,9 \%)$.

Nadat toestemming was verkregen werd er een afspraak gemaakt voor een thuisbezoek. Tijdens dit thuisbezoek vond de dataverzameling plaats, waarbij allebei de ouders en de twee adolescenten afzonderlijk van elkaar vragenlijsten invulden onder begeleiding van een getrainde interviewer. In totaal deden 288 gezinnen mee aan de eerste meetronde, en 285 gezinnen aan de tweede en derde meetronde. Tussen de meetrondes zat ongeveer een jaar tijd. Slechts drie gezinnen stopten tijdens de loop van het onderzoek met hun deelname.

Alle deelnemende gezinnen hadden de Nederlandse nationaliteit, en de meeste behoorden tot de middenklasse.

Als twee kinderen in hetzelfde gezin wordt gevraagd om over hun relatie met hun ouders te rapporteren, kan onderlinge afhankelijkheid van de data een probleem zijn. Dit probleem werd opgelost door voor de analyses willekeurig één van de twee adolescenten te kiezen, waarvan $50 \%$ de oudere adolescent en $50 \%$ de jongere adolescent van de twee deelnemende adolescenten was.

Voor het huidige onderzoek zijn de gegevens van 285 adolescenten gebruikt over de gehechtheidsrelaties met hun moeder en vader, en over hun eigen internaliserend en externaliserend probleemgedrag. Van al deze adolescenten hebben we gegevens over drie meetmomenten, met intervallen van één jaar tussen de meetmomenten.

De gemiddelde leeftijd van deze adolescenten was 13,5 jaar tijdens de eerste meetronde (range 11,1 - 15,8 jaar). Van de gebruikte steekproef was $48,6 \%$ van het mannelijke en $51,4 \%$ van het vrouwelijke geslacht. De gemiddelde leeftijd van moeders tijdens de eerste meetronde was 41,6 jaar en de gemiddelde leeftijd van vaders tijdens de eerste meetronde was 43,9 jaar.

\section{Meetinstrumenten}

\section{Kwaliteit van gehechtheid}

De Inventory of Parent and Peer Attachment (IPPA; Armsden \& Greenberg, 1987) is gebruikt om de kwaliteit van de gehechtheidsrelaties van adolescenten met vader en moeder te meten. De IPPA is ontworpen om percepties van adolescenten betreffende gehechtheidsrelaties met specifieke gehechtheidsfiguren (vader en moeder apart) te meten door in te gaan op de positief affectieve/cognitieve ervaringen van goede communicatie en vertrouwen in de beschikbaarheid en responsiviteit van gehechtheidsfiguren, alsmede de negatief affectieve/cognitieve ervaringen van de boosheid en/of hopeloosheid die het gevolg zijn van niet-responsieve of inconsistent responsieve gehechtheidsfiguren (Armsden \& Greenberg, 1987).

De IPPA is een zelfrapportagelijst die voor de antwoorden gebruik maakt van een vijfpunts Likertschaal (van $1=$ klopt erg slecht tot $5=$ klopt erg goed). Op basis van de resultaten van eerder onderzoek (Deković \& Meeus, 1997) zijn de twee items met de laagste item-totaal correlatiecoëfficiënten verwijderd uit de aangepaste IPPA (Raja e.a., 1992), waardoor een schaal met tien items ontstond.

De IPPA heeft drie subschalen. De Communicatie-schaal heeft drie items en gaat de mate na waarin een adolescent in staat is om goed met zijn/haar ouders te communiceren. Een voorbeelditem is: 'Als mijn vader/moeder weet dat ik met iets zit dan vraagt hij/zij dat aan mij'. De Vertrouwen-schaal bestaat ook uit drie items en meet in hoeverre een adolescent er vertrouwen in heeft dat ouders zijn of haar gevoelens en wensen respecteren en accepteren. Een voorbeelditem is: 'Mijn vader/moeder respecteert mijn gevoelens'. De Vervreemding-schaal bestaat uit vier items en meet in hoeverre een adolescent negatieve gevoelens heeft ten opzichte van ouders. Een voorbeelditem is: 'Ik krijg niet veel aandacht van mijn vader/moeder'. Voor de relaties met moeder en vader werden identieke items gebruikt. De Vervreemding-schaal is gehercodeerd en in latere analyses Warmte genoemd. In de analyses zijn de schalen Communicatie, Vertrouwen en Warmte gebruikt als indices van de kwaliteit van de gehechtheid.

In een aantal overzichtsartikelen over meetinstrumenten voor de kwaliteit van de gehechtheid van adolescenten aan ouders werd geconcludeerd dat de IPPA een valide en betrouwbaar meetinstrument is voor de perceptie van de kwaliteit van de gehechtheid aan ouders (bv., Lopez \& Gover, 1993; Lyddon, Bradford, \& Nelson, 1993). In ons onderzoek bleek de betrouwbaarheid (Cronbachs alfa) van de IPPA goed, 0,81 voor zowel gehechtheid aan moeder als gehechtheid aan vader op tijdstip 1. Op tijdstip 2 waren de alfa's 0,84 voor moeder en vader, en op tijdstip 30,85 voor beide ouders.

\section{Probleemgedrag}

Internaliserend en externaliserend probleemgedrag werden gemeten door de Nijmegen Problem Behavior List (NPBL-Research version; Scholte, Vermulst, \& De Bruyn, 2001). De schaal bestaat uit twintig items. De items werden geformuleerd op basis van hun toepasbaarheid op een subklinische populatie, en vertegenwoordigen relevante problemen in de adolescentie die aandacht behoeven, maar niet serieus genoeg zijn voor klinische 
interventie. De items zijn door de adolescent beoordeeld op een vijfpuntsschaal $(1=$ klopt erg slecht tot $5=\mathrm{klopt}$ erg goed).

In het huidige onderzoek werden vier schalen gebruikt met elk vijf items: Teruggetrokken gedrag, Angst/Depressie, Delinquent gedrag en Agressief gedrag. Teruggetrokken gedrag en Angst/Depressie zijn gebruikt als indicatoren voor internaliserend probleemgedrag, en meten in hoeverre adolescenten zichzelf terugtrekken, en angst en depressie ervaren (bv. 'Ik voel me verdrietig, ongelukkig'). Interne consistenties (Cronbachs alfa) voor Teruggetrokken gedrag en Angst/Depressie waren respectievelijk 0,73 en 0,74 op tijdstip 1 (T1), 0,75 en 0,78 op tijdstip 2 (T2), en 0,80 en 0,81 op tijdstip 3 (T3). De schalen Delinquentie en Agressief gedrag zijn indicatoren voor externaliserend probleemgedrag en meten in hoeverre adolescenten delinquent en agressief gedrag vertonen (bv. 'Ik maak veel ruzie'). Interne consistenties voor Delinquentie en Agressief gedrag waren respectievelijk 0,66 en 0,74 op tijdstip 1, 0,69 en 0,78 op tijdstip 2, en 0,75 en 0,78 op tijdstip 3 .

De intercorrelaties tussen de verschillende schalen voor internaliserend en externaliserend probleemgedrag waren alle significant $(p<0,01)$, met een gemiddelde correlatie van 0,37 en een range van 0,30 (Agressie Angst/Depressie op T1) tot 0,43 (Agressie - Angst/Depressie op T3).

Om de validiteit van dit meetinstrument te bepalen kregen adolescenten bij het derde meetmoment twee aanvullende vragenlijsten voor het meten van probleemgedrag. Het eerste meetinstrument was de Vragenlijst Deviant Gedrag (alfa $=0,83$ ). Deze vragenlijst van achttien items bestrijkt een breed palet aan oppositionele en delinquente gedragingen, van relatief onschuldige daden als ongehoorzaamheid ten opzichte van de ouders en te laat thuis komen tot ernstiger overtredingen als het gebruiken van harddrugs, iemand met opzet slaan, winkeldiefstel, enzovoort (Deković, 1999). Het tweede meetinstrument was de Depressive Mood List (Kandel \& Davies, 1982) (6 items, alfa= 0,76). De correlatie tussen de scores van de adolescenten op deze instrumenten en de scores op de overeenkomstige NPBL-schalen was 0,78 voor de Vragenlijst Deviant Gedrag en 0,82 voor de Depressive Mood List, waaruit een acceptabele validiteit blijkt.

\section{Data-analytische strategieën}

\section{Meetmodel}

De wederkerige invloeden tussen de kwaliteit van de gehechtheid aan vader en moeder enerzijds en het probleemgedrag anderzijds werden apart bekeken voor elk van de twee soorten probleemgedrag. Dit werd gedaan met behulp van structurele vergelijkingsmodellen, in twee afzonderlijke wederkerige effect-modellen met drie meetmomenten (LISREL 8; Jöreskog \& Sörbom, 1993).

In beide modellen (gehechtheid-internaliserend probleemgedrag en gehechtheid-externaliserend probleemgedrag) werd de kwaliteit van de gehechtheid aan vader en moeder opgevat als een latente variabele, opgebouwd uit de scores op de drie IPPA-subschalen Communicatie, Vertrouwen en Warmte.

De latente variabele internaliserend probleemgedrag was opgebouwd uit de twee afzonderlijke schalen Teruggetrokken gedrag en Angst/Depressie, en de latente variabele externaliserend probleemgedrag uit de schalen Delinquentie en Agressie. In elk van deze twee modellen werden de twee latente variabelen (gehechtheid en respectievelijk internaliserend of externaliserend probleemgedrag) voor alle drie meetmomenten geformuleerd. Dit resulteerde in een totaal van zes latente variabelen in elk basismodel. In alle modellen mochten de meetfouten van dezelfde geobserveerde scores onderling covariëren (Farrell, 1994). In deze fase van de analyses werden er nog geen paden geformuleerd tussen de latente variabelen.

De $x^{2}$-waarde, bijbehorende $p$-waarde, de 'root mean square error of approximation' (RMSEA), en de 'nonnormed fit index' (NNFI) werden gebruikt om de algemene 'fit' van elk model te bepalen. Goed passende modellen hebben niet-significante chi-kwadraten, maar deze maat is erg gevoelig voor de steekproefgrootte (Schumacker \& Lomax, 1996). Daarom keken we ook naar twee andere fit indices die minder gevoelig zijn voor steekproefgrootte, de RMSEA en de NNFI, om de fit van de modellen te bepalen (Fan, Thompson, \& Wang, 1999). Waarden van de RMSEA beneden de 0,05 impliceren een goede fit, en waarden tussen de 0,05 en 0,08 een acceptabele fit tussen model en data (Browne \& Cudeck, 1993). Bij een goede fit zou de NNFI 0,90 of hoger moeten zijn (Bartle-Haring \& Gavazzi, 1996; Marsh \& Hocevar, 1988).

De algemene fit van het meetmodel werd getoetst in een confirmatieve factoranalyse, en bleek voldoende te zijn met $X^{2}(63)=211,46, p<0,01$, RMSEA $=0,09$ en NNFI $=0,89$ voor het model betreffende gehechtheid en internaliserend probleemgedrag, en $X^{2}(63)=176,32, p<0,01$, RMSEA $=0,08$ en NNFI = 0,92 voor het model betreffende kwaliteit van gehechtheid en externaliserend probleemgedrag.

Om te kijken of er verschillen tussen de meetmomenten waren voor wat betreft de factorladingen werd hierna de meetequivalentie getoetst door middel van het vergelijken van drie modellen. In het eerste model waren de factorladingen van dezelfde geobserveerde scores op de latente variabelen alsmede de meetfouten van de geobserveerde scores gelijkgesteld voor alle drie meetmomenten. In het tweede model werden de factorladingen van de geobserveerde scores gelijkgesteld voor de drie meetmomenten en de meetfouten van de geobserveerde scores werden voor elke meetronde apart geschat. In het derde model werden zowel de factorladingen als de meetfouten van de geobserveerde scores voor elke meetronde apart geschat. Deze drie modellen hebben we vergeleken. De verandering in $\mathrm{X}^{2}$ van het eerste naar het tweede model was $\Delta \mathrm{X}^{2}(10)=19, p<0,05$ voor internaliserend gedrag, en $\Delta x^{2}(10)=42, p<0,001$ voor externaliserend gedrag. Veranderingen in $x^{2}$ van het tweede naar het derde model waren voor zowel internaliserend als externaliserend probleemgedrag niet significant, wat betekent dat het tweede model het beste bij de data paste.

Dat betekent dat er geen verschillen zijn gevonden tussen de meetmomenten wat betreft de factorladingen van de geobserveerde scores op de latente variabelen. Op basis van deze resultaten werden de factorladingen 
voor de drie meetmomenten gelijkgesteld, en werden de meetfouten los geschat. Deze meetmodellen werden gebruikt in de volgende analyses waarin de structurele relaties tussen de latente variabelen werden onderzocht.

\section{Structureel model}

Op basis van theoretische en empirische overwegingen formuleerden we structurele modellen waarin de kwaliteit van de gehechtheid en het probleemgedrag (respectievelijk internaliserend en externaliserend) verondersteld werden stabiliteit over de tijd te vertonen. Daarnaast verwachtten we dat ze elkaar ook zouden beïnvloeden. In het basismodel werden de correlatie tussen de kwaliteit van de gehechtheid en het probleemgedrag op tijdstip 1 , en onderlinge wederkerige verbanden geschat. We verwachtten dat de kwaliteit van de gehechtheid redelijk stabiel zou zijn van tijdstip 1 naar tijdstip 2, en dat deze een effect zou hebben op het probleemgedrag op tijdstip 2. Ook internaliserend en externaliserend probleemgedrag werden verondersteld een zekere mate van stabiliteit te vertonen van tijdstip 1 naar tijdstip 2, en gehechtheid op tijdstip 2 te beïnvloeden. Dezelfde paden werden geformuleerd voor het verband tussen de kwaliteit van de gehechtheid en de twee soorten probleemgedrag op tijdstip 2 en tijdstip 3. Na het toetsen van deze basismodellen werden niet-significante paden verwijderd, waarna de modellen opnieuw werden getoetst.

De structurele modellen werden ook gecheckt op geslachtsverschillen. We creëerden vier groepen op basis van het geslacht van de adolescent en van de ouder (jongens-vader, jongens-moeder, meisjes-vader, meisjesmoeder), en stelden drie modellen op. In het eerste model werden alle padcoëfficiënten, meetfoutvarianties en -covarianties gelijkgesteld tussen de vier groepen. In het tweede model werden alleen de padcoëfficiënten gelijkgesteld tussen de vier groepen, en in het derde model werden ook de padcoëfficiënten voor de vier groepen apart geschat. Hierna keken we of model 2 of model 3 een betere fit opleverden dan het eerste model (waarin alle paden gelijk waren gesteld) (Farrell, 1994). Niet-significante veranderingen in $x^{2}$ van het eerste naar het tweede model $\left(\Delta \mathrm{x}^{2}(27)=24, p>0,05\right.$ voor internaliserend, en $\Delta \mathrm{x}^{2}(27)=16, p>0,05$ voor externaliserend probleemgedrag) geven aan dat het eerste model beter past bij de data. Veranderingen in $x^{2}$ van het eerste (en tweede) naar het derde model waren ook niet significant. Het eerste model lijkt dus het best passende model te zijn voor het verband tussen de kwaliteit van de gehechtheid enerzijds en internaliserend en externaliserend gedrag anderzijds. Op basis hiervan concluderen we dat er geen geslachtsverschillen zijn in deze verbanden, en de hierna gerapporteerde resultaten zijn gebaseerd op analyses waarin alle padcoëfficiënten en meetfoutvarianties en -covarianties gelijkgesteld zijn voor jongens en meisjes en voor hun relaties met moeders en vaders.

\section{Resultaten}

\section{Verbanden tussen geobserveerde variabelen}

Tabellen $1 \mathrm{t} / \mathrm{m} 3$ laten de correlaties zien tussen de geobserveerde variabelen op elk meetmoment. De sterk significante correlaties tussen de meetmomenten wat betreft geobserveerde scores van hetzelfde concept, respectievelijk de kwaliteit van de gehechtheid (zie tabel 1), het internaliserend (zie tabel 2) en het externaliserende probleemgedrag (zie tabel 3) wijzen erop dat deze concepten een hoge mate van stabiliteit vertonen.

De gehechtheidsschalen en de schalen voor internaliserend en externaliserend probleemgedrag correleren significant met elkaar, zowel binnen als tussen meetmoment (zie tabel 2 en 3 ). 
Tabel 1 Intercorrelaties (cross-sectioneel en stabiliteitscoëfficiënten) tussen indicatoren voor gehechtheid. Gehechtheid

\section{Tijdstip 1}

12
Tijdstip 2

4
Tijdstip 3

$\begin{array}{llllll}3 & 4 & 5 & 6 & 7 & 8\end{array}$

Tijdstip 1

1. Communicatie

2. Vertrouwen

$0,63^{* *}$

3. Warmte

$0,44^{* *} \quad 0,56^{* *}$

Tijdstip 2
4. Communicatie
$0,63^{* *} \quad 0,50^{* *} \quad 0,43^{* *}$
5. Vertrouwen
$0,48^{* *} \quad 0,56^{* *} \quad 0,41^{* *} \quad 0,67^{* *}$
6. Warmte
$0,39^{* *} \quad 0,43^{\star *} \quad 0,55^{\star *} \quad 0,50^{* *} \quad 0,59^{* *}$
Tijdstip 3
7. Communicatie
$0,52^{\star *} \quad 0,37^{* *} \quad 0,35^{\star *} \quad 0,66^{\star *} \quad 0,43^{* *} \quad 0,37^{* *}$
8. Vertrouwen
$0,41^{* *} \quad 0,51^{* *} \quad 0,46^{* *} \quad 0,55^{* *} \quad 0,92^{* *} \quad 0,47^{* *} \quad 0,60^{* *}$
9. Warmte
$0,36^{\star *}$
$0,40^{\star *} \quad 0,51^{* *}$
$0,47^{* *} \quad 0,44^{* *}$
$0,68^{* *} \quad 0,52^{* *} \quad 0,60^{* *}$
${ }^{* *} p<0,01$
Cursieve correlaties: stabiliteit tussen meetmomenten van hetzelfde concept. 
Tabel 2 Intercorrelaties (cross-sectioneel en stabiliteitscoëfficiënten) tussen indicatoren voor gehechtheid en internaliserend probleemgedrag.

Internaliserend probleemgedrag

Gehechtheid

Tijdstip 1

Tijdstip 2

Tijdstip 3 Tijdstip 1

\section{Tijdstip 2}

$\begin{array}{lll}6 & 7 & 8\end{array}$

$-0,22^{* *}-0,24^{* *}-0,29^{* *}-0,26^{* *}-0,24^{* *}-0,31^{* *}$

1. Teruggetrokken

2. Angst/depressie $\quad 0,52^{* *}$

Tijdstip 2

$\begin{array}{llllll}\text { 3. Teruggetrokken } & 0,53^{* *} & 0,40^{* *} & & & \\ \text { 4. Angst/depressie } & 0,35^{* *} & 0,59^{* *} & 0,59^{* *} & & \\ \text { Tijdstip 3 } & & & & & \\ \text { 5. Teruggetrokken } & 0,46^{* *} & 0,31^{* *} & 0,65^{* *} & 0,42^{* *} & \\ \text { 6. Angst/depressie } & 0,40^{* *} & 0,50^{* *} & 0,50^{* *} & 0,67^{* *} & 0,66^{* *}\end{array}$
${ }^{* *} p<0,01$

Variabelen 7, 10 en 13 zijn de scores op de IPPA Communicatie-subschaal.

Variabelen 8, 11 en 14 zijn de scores op de IPPA Vertrouwen-subschaal.

Variabelen 9, 12 en 15 zijn de scores op de IPPA Warmte-subschaal.

Cursieve correlaties: stabiliteit tussen meetmomenten van hetzelfde concept.

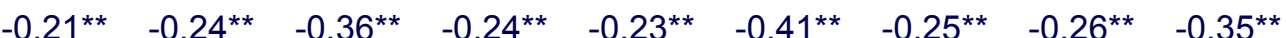

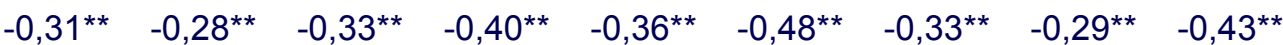

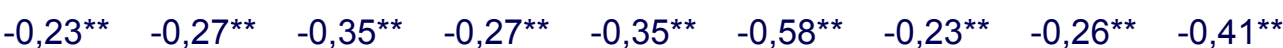

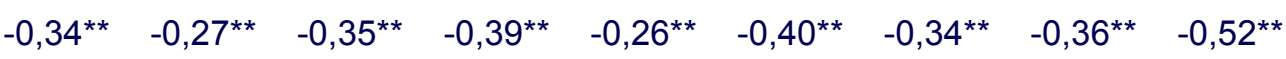

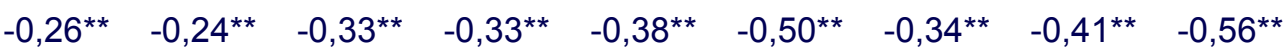


Tabel 3 Intercorrelaties (cross-sectioneel en stabiliteitscoëfficiënten) tussen indicatoren voor gehechtheid en externaliserend probleemgedrag.

\section{Externaliserend probleemgedrag Gehechtheid}

\section{Tijdstip $1 \quad$ Tijdstip $2 \quad$ Tijdstip 3 Tijdstip 1}

$12 \quad 3 \quad 4$

5

67

Tijdstip 2

Tijdstip 1

1. Delinquentie

2. Agressie $0,52^{* *}$

Tijdstip 2

$\begin{array}{lllllll}\text { 3. Delinquentie } & 0,54^{* *} & 0,37^{* *} & & & \\ \text { 4. Agressie } & 0,39^{* *} & 0,56^{* *} & 0,67^{* *} & & \\ \text { Tijdstip } 3 & & & & & \\ 5 . \quad \text { Delinquentie } & 0,49^{* *} & 0,35^{* *} & 0,59^{* *} & 0,51^{* *} & \\ 6 . \quad \text { Agressie } & 0,36^{* *} & 0,45^{* *} & 0,47^{* *} & 0,63^{* *} & 0,66^{* *} \\ { }^{*}<0,05^{* *}<<0,01 & & & & & \end{array}$

$\begin{array}{lllllllll}-0,13^{*} & -0,29^{* *} & -0,37^{* *} & -0,13^{*} & -0,26^{* *} & -0,31^{* *} & -0,16^{* *} & -0,23^{* *} & -0,32^{* *} \\ -0,16^{* *} & -0,32^{* *} & -0,42^{* *} & -0,17^{* *} & -0,29^{* *} & -0,31^{* *} & -0,16^{* *} & -0,29^{* *} & -0,27^{* *} \\ -0,23^{* *} & -0,30^{* *} & -0,43^{* *} & -0,25^{* *} & -0,35^{* *} & -0,48^{* *} & -0,20^{* *} & -0,30^{* *} & -0,42^{* *} \\ -0,14^{*} & -0,29^{* *} & -0,39^{* *} & -0,23^{* *} & -0,33^{* *} & -0,47^{* *} & -0,21^{* *} & -0,33^{* *} & -0,43^{* *} \\ & & & & & & & & \\ -0,18^{* *} & -0,25^{* *} & -0,36^{* *} & -0,21^{* *} & -0,28^{* *} & -0,38^{* *} & -0,31^{* *} & -0,41^{* *} & -0,50^{* *} \\ -0,18^{* *} & -0,25^{* *} & -0,34^{* *} & -0,24^{* *} & -0,30^{* *} & -0,34^{* *} & -0,28^{* *} & -0,43^{* *} & -0,50^{* *}\end{array}$

Variabelen 7,10 en 13 zijn de scores op de IPPA Communicatie-subschaal.

Variabelen 8, 11 en 14 zijn de scores op de IPPA Vertrouwen-subschaal.

Variabelen 9, 12 en 15 zijn de scores op de IPPA Warmte-subschaal.

Cursieve correlaties: stabiliteit tussen meetmomenten van hetzelfde concept. 


\section{Kwaliteit van gehechtheid en internaliserend probleemgedrag}

Ons basismodel voor het verband tussen de kwaliteit van de gehechtheid van adolescenten aan ouders enerzijds en hun internaliserend probleemgedrag anderzijds (waarin zowel stabiliteit als wederkerige effecten werden verondersteld) bleek een acceptabele fit te hebben. Niet-significante paden werden verwijderd uit het model, waarna het opnieuw werd getoetst. Dit resulteerde in een $X^{2}(342)=597,71, p<0,01$. De RMSEA $(0,07)$ en de NNFI $(0,93)$ waren goed.

De kwaliteit van de gehechtheid was over de meetmomenten heen stabiel (zie figuur 1), met padcoëfficiënten van 0,71 (tijdstip 1 - tijdstip 2) en 0,78 (tijdstip 2 - tijdstip 3). Internaliserend probleemgedrag was ook stabiel, met padcoëfficiënten van 0,64 (tijdstip 1 - tijdstip 2) en 0,84 (tijdstip 2 - tijdstip 3). Het verschil tussen deze twee stabiliteitscoëfficiënten is significant $\left(\Delta \mathrm{x}^{2}(1)=6, p<0,05\right)$, wat erop wijst dat de stabiliteit van internaliserend probleemgedrag toeneemt gedurende de tijd.

Er waren significante negatieve correlaties tussen de kwaliteit van de gehechtheid en het internaliserende probleemgedrag op elk meetmoment, $-0,29,-0,13$ en $-0,12$ op respectievelijk tijdstip 1 , tijdstip 2 en tijdstip 3 . De correlatie op tijdstip 1 vertegenwoordigt de initiële correlatie tussen de twee constructen, en de correlaties op tijdstip 2 en tijdstip 3 de correlaties tussen de residuen.

De resultaten laten significante wederkerige paden zien van tijdstip 1 naar tijdstip 2 . Internaliserend probleemgedrag op tijdstip 2 wordt significant beïnvloed door de kwaliteit van de gehechtheid een jaar eerder, met een padcoëfficiënt $(\beta)$ van $-0,20$ van de kwaliteit van de gehechtheid op tijdstip 1 naar internaliserend probleemgedrag op tijdstip 2. De kwaliteit van de gehechtheid op tijdstip 2 wordt ook significant beïnvloed door het internaliserend probleemgedrag een jaar eerder, met een padcoëfficiënt $(\beta)$ van $-0,13$. Tussen tijdstip 2 en tijdstip 3 werden geen significante wederkerige padcoëfficiënten gevonden.

Figuur 1 Padmodel gehechtheid en internaliserend probleemgedrag.

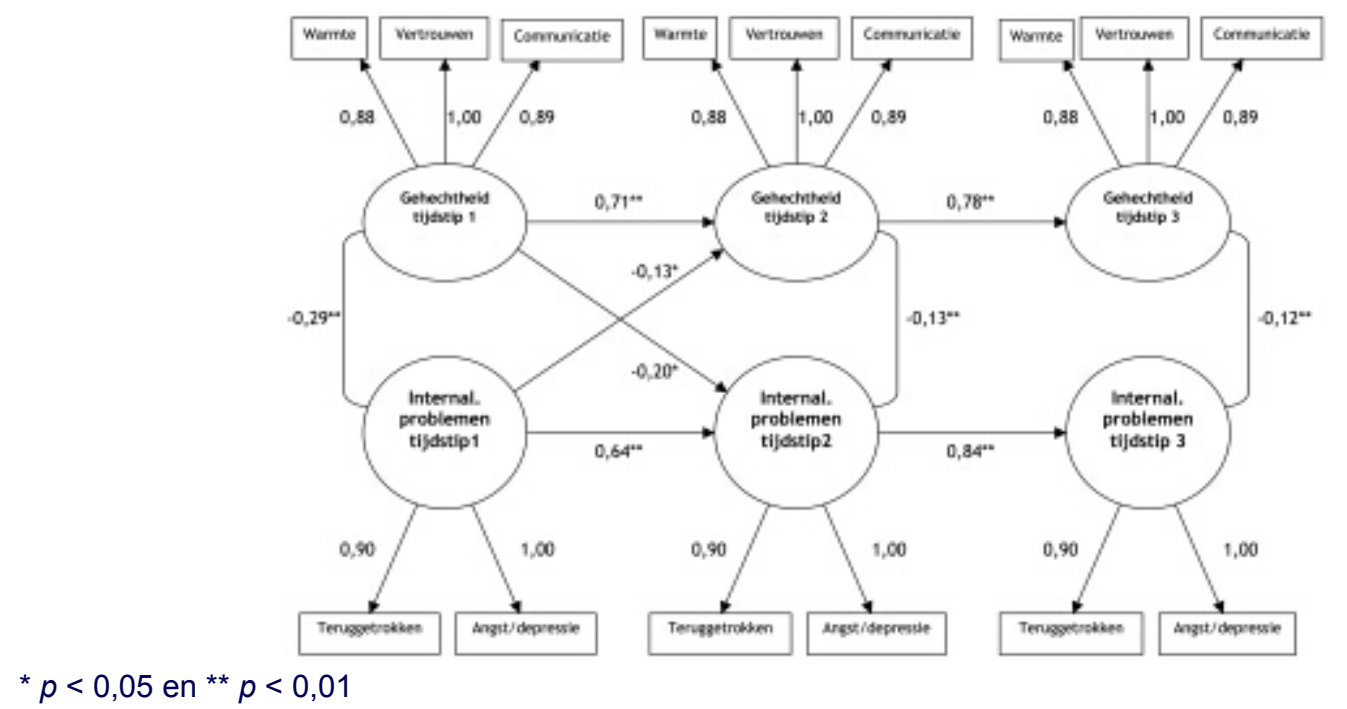

Kwaliteit van gehechtheid en externaliserend probleemgedrag

Het basismodel, waarin stabiliteit van de kwaliteit van de gehechtheid en het externaliserende probleemgedrag alsmede wederkerige invloeden tussen de twee concepten werd verondersteld, had wederom een goede fit. We pasten het model aan door niet-significante paden te verwijderen, hetgeen resulteerde in een $X^{2}(342)=486,86, p$ $<0,01$. De RMSEA $(0,05)$ en de NNFI $(0,95)$ waren goed.

De kwaliteit van de gehechtheid en het externaliserende probleemgedrag zijn beide redelijk stabiel (zie figuur 2). Padcoëfficiënten voor de kwaliteit van de gehechtheid waren 0,77 en 0,72 voor respectievelijk tijdstip 1 tijdstip 2 en tijdstip 2 - tijdstip 3, en die voor externaliserend probleemgedrag 0,62 voor tijdstip 1 - tijdstip 2 en 0,72 voor tijdstip 2 - tijdstip 3.

Er waren significante, negatieve correlaties tussen de kwaliteit van de gehechtheid en het externaliserende probleemgedrag op elk meetmoment, $-0,29,-0,09$ en $-0,15$ op respectievelijk tijdstip 1, tijdstip 2 en tijdstip 3.

Wat betreft de wederkerige paden tussen de twee latente variabelen bleek dat de kwaliteit van de gehechtheid op tijdstip 1 een significante invloed had op het externaliserende probleemgedrag op tijdstip 2 (padcoëfficiënt $\beta=-0,19$ ). Het externaliserende probleemgedrag op tijdstip 2 had weer een significante invloed op de kwaliteit van de gehechtheid op tijdstip 3 (padcoëfficiënt $\beta=-0,12$ ). 


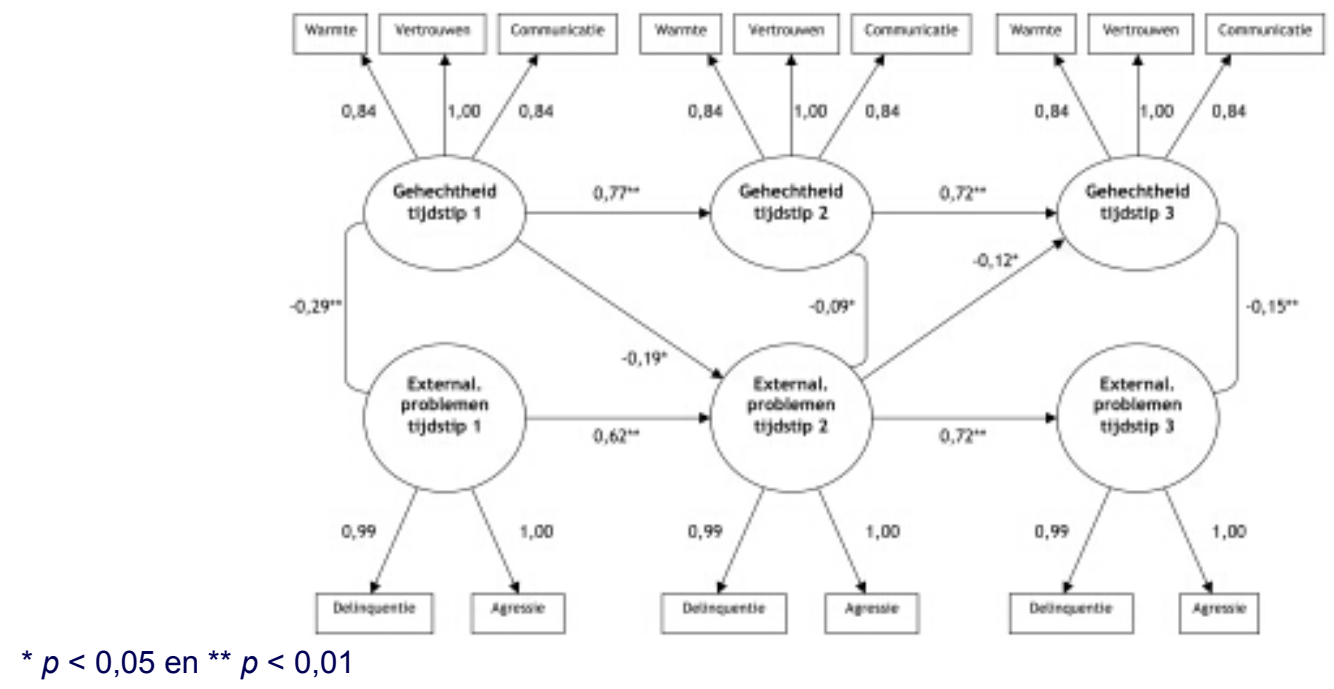

\section{Discussie}

Het doel van het huidige onderzoek was om het wederkerige verband tussen de kwaliteit van de gehechtheid en het probleemgedrag van adolescenten te onderzoeken in een longitudinale opzet met drie meetmomenten. De resultaten laten zien dat de kwaliteit van de gehechtheid en de beide soorten probleemgedrag een zekere mate van stabiliteit vertonen, en dat ze elkaar weliswaar in beperkte mate, maar toch significant beïnvloeden.

Het negatieve verband tussen de kwaliteit van de gehechtheid aan ouders en het internaliserende probleemgedrag van de adolescent binnen de meetmomenten werd ook in eerder onderzoek gevonden (Allen e.a., 1998; Armsden, McCauley, Greenberg, Burke, \& Mitchell, 1990; Laible e.a., 2000; Raja e.a., 1992). Gehechtheid en internaliserend probleemgedrag beïnvloeden elkaar ook in de loop van de tijd, hetgeen bleek uit de significante wederkerige paden van tijdstip 1 naar tijdstip 2. Adolescenten die een hogere kwaliteit van gehechtheid aan ouders rapporteren vertonen een jaar later minder internaliserend probleemgedrag. Omgekeerd is het ook zo dat adolescenten die meer internaliserend probleemgedrag vertonen een jaar later een lagere kwaliteit van gehechtheid aan ouders hebben. Binnen een relatie met ouders die gekarakteriseerd wordt door warmte en vertrouwen ontwikkelen adolescenten eerder een positief zelfbeeld en vertrouwen in hun eigen succes in het overwinnen van de uitdagingen die de adolescentie eigen zijn (Shreeber, Hops, \& Davis, 2001).

Het feit dat de wederkerige paden van tijdstip 2 naar tijdstip 3 niet significant bleken te zijn, zou verklaard kunnen worden door het feit dat internaliserende problemen meer stabiel lijken te zijn van tijdstip 2 naar tijdstip 3 vergeleken met de stabiliteit van tijdstip 1 naar tijdstip 2. Deze toenemende stabiliteit van internaliserend probleemgedrag hangt samen met minder veranderingen. Minder veranderingen in internaliserend probleemgedrag betekenen ook minder veranderingen die te verklaren vallen door de kwaliteit van de gehechtheid. Het zou dus kunnen zijn dat de kwaliteit van de gehechtheid vooral van invloed is op het ontstaan van internaliserende problemen, en dat deze problemen, als ze zich eenmaal gemanifesteerd hebben, vrij stabiel zijn en minder snel veranderen. Er is meer onderzoek nodig om meer helderheid te krijgen in deze wederkerige processen tijdens de adolescentie.

Het patroon voor externaliserend probleemgedrag lijkt erg op dat van internaliserende problemen. Naast een verband tussen de kwaliteit van de gehechtheid en externaliserende problemen binnen de meetmomenten vonden we ook een significant remmende invloed van gehechtheid op externaliserend probleemgedrag een jaar later. Deze bevindingen komen overeen met die van eerder (cross-sectioneel) onderzoek (Allen e.a., 1998; Laible e.a., 2000; Marcus \& Betzer, 1996). Adolescenten die een hoge kwaliteit van gehechtheid aan ouders rapporteren, hebben een jaar later minder probleemgedrag. Relaties met ouders die door de adolescent als positief gezien worden lijken de kans te verkleinen dat de adolescent 'acting-out' en regelovertredend gedrag vertoont. Andersom, als de relatie met zijn/haar ouders door een adolescent als negatief wordt ervaren en gekarakteriseerd wordt door gebrek aan warmte, communicatie en vertrouwen is de kans groter dat de adolescent zijn/haar ongenoegen uit door middel van delinquent en agressief gedrag. Ook hier was het zo dat niet alle vier mogelijke wederkerige effecten tussen de kwaliteit van de gehechtheid en externaliserende problemen significant waren. Externaliserend probleemgedrag neemt ook toe in stabiliteit gedurende de vroege en midden-adolescentie (alhoewel niet significant), en lijkt minder vatbaar voor beïnvloeding als deze problemen er eenmaal zijn. Op hun beurt hebben externaliserende problemen een negatief effect op de (perceptie van de) relatie van de adolescent met zijn/haar ouders. Het zou interessant zijn om te kijken of de perceptie van de ouders omtrent hun relatie met hun adolescente kinderen op dezelfde wijze negatief beïnvloed wordt door externaliserend probleemgedrag van de adolescent.

Het huidige onderzoek kent een aantal beperkingen. Voor elk van de latente variabelen internaliserend en externaliserend probleemgedrag hebben we slechts twee indicatoren (schalen) gebruikt. Het zou wellicht 
methodologisch gezien eleganter zijn geweest om meer indicatoren te gebruiken. Aan de andere kant zou dat geresulteerd hebben in complexere structurele en meetmodellen met een bijbehorende grotere kans op analysetechnische (identificatie-)problemen.

Een andere beperking van het onderzoek is dat we alleen zelfrapportage hebben gebruikt voor zowel het probleemgedrag als de kwaliteit van de gehechtheid. Hierdoor zijn de verbanden misschien sterker dan ze in werkelijkheid zijn. Er waren echter legitieme redenen voor deze aanpak. In de eerste plaats is gehechtheid een sterk geïnternaliseerde relatie, en ouders vragen om te rapporteren over hoe hun kinderen de relatie met hen ervaren vonden we niet zinvol. Er zijn uiteraard ook methoden, om in plaats van de perceptie van de adolescent te vragen, de kwaliteit van de gehechtheid door beoordelaars te laten vaststellen, bijvoorbeeld met het Adult Attachment Interview (AAl; George, Kaplan, \& Main, 1985). Dergelijke methoden waren voor ons vanwege de omvang van de onderzoeksgroep (in totaal 288 gezinnen met elk vier respondenten op drie meetmomenten) niet geschikt. In de tweede plaats kan het gebruiken van ouderrapportages voor het meten van internaliserend en externaliserend probleemgedrag ook nadelen hebben. Uit onderzoek is gebleken dat ouders systematisch lagere schattingen geven van probleemgedrag bij hun kinderen dan de kinderen zelf (Verhulst \& Koot, 1995). Vooral de mate van internaliserend probleemgedrag lijkt moeilijk in te schatten voor ouders, waarschijnlijk omdat het minder zichtbaar is dan externaliserende problemen. Hier komt nog bij dat als er daadwerkelijk 'bias' aanwezig zou zijn in het oordeel van adolescenten, dit alleen de initiële correlatie tussen de kwaliteit van de gehechtheid en het probleemgedrag zou kunnen verklaren, maar niet de wederkerige effecten omdat deze gecontroleerd worden voor de initiële correlatie.

Tot slot staan we stil bij het feit dat onze respondenten behoorden tot relatief goed functionerende tweeoudergezinnen, voornamelijk uit de middenklasse. De vraag of onze bevindingen gegeneraliseerd kunnen worden naar gezinnen met andere sociale achtergronden, en naar minder goed functionerende gezinnen is nog niet beantwoord. Het zou verhelderend zijn om het huidige onderzoek uit te breiden naar een groep families waarvan de adolescente kinderen een grotere diversiteit vertonen wat betreft ernst van probleemgedrag.

Niettegenstaande deze overwegingen kunnen we toch een aantal conclusies trekken. Ten eerste, ondanks de relatief hoge stabiliteit van zowel de kwaliteit van de gehechtheid als het probleemgedrag over een periode van drie jaar, werden toch significante wederkerige relaties gevonden tussen deze concepten. Ten tweede, alhoewel er kleine verschillen waren in het verband tussen de kwaliteit van de gehechtheid en het internaliserende probleemgedrag enerzijds en de kwaliteit van de gehechtheid en het externaliserende probleemgedrag anderzijds was het patroon van de bevindingen grotendeels hetzelfde. Met andere woorden, de wederkerige relaties tussen de kwaliteit van de gehechtheid aan ouders en het probleemgedrag lijkt hetzelfde te zijn voor beide soorten probleemgedrag.

Een belangrijke bijdrage van het huidige onderzoek aan al bestaand onderzoek op het gebied van gehechtheid en probleemgedrag tijdens de adolescentie is de toepassing van een kortlopend longitudinaal 'design'. Veel van het bestaande onderzoek is cross-sectioneel van aard, wat de mogelijkheid om uitspraken te doen over de richting van effecten sterk beperkt. Er zijn wel een aantal longitudinale onderzoeken uitgevoerd naar gehechtheid en psychosociaal functioneren van de adolescent, maar in deze onderzoeken werd gekeken in hoeverre de kwaliteit van de gehechtheid van zeer jonge kinderen en baby's voorspellend is voor het functioneren tijdens de adolescentie (Hamilton, 2000; Waters, Merrick, Treboux, Crowell, \& Albersheim, 2000; Weinfield, Sroufe, \& Egeland, 2000). Deze onderzoeken geven belangrijke inzichten in de langetermijneffecten van de kwaliteit van de gehechtheid op het psychosociaal functioneren, maar verstrekken geen informatie over de wederkerigheid tussen deze twee concepten. Door toepassing van een kortlopend longitudinaal design waren we in staat om aannames over deze wederkerigheid en over de richting van effecten statistisch te toetsen.

Door gezinnen te bestuderen die meer divers zijn wat betreft psychosociale aanpassing en door meerdere informanten te gebruiken, kan toekomstig onderzoek ons inzicht verdiepen in de processen omtrent wederkerige invloeden tussen de kwaliteit van de gehechtheid en het probleemgedrag tijdens de adolescentie. In aanvulling hierop suggereren de relatief hoge stabiliteitscoëfficiënten die in het huidige onderzoek zijn gevonden dat adolescenten gedurende de tijd ongeveer dezelfde onderlinge rangorde houden wat betreft de kwaliteit van de gehechtheid en het probleemgedrag. Het zou verhelderend kunnen zijn om individuele veranderingspatronen in de kwaliteit van de gehechtheid en het probleemgedrag en hun onderlinge wederkerige invloeden te bestuderen. Onderzoek met deze optiek suggereert dat het misschien niet zozeer het beginniveau van de kwaliteit van gezinsrelaties is dat gerelateerd is aan probleemgedrag, maar juist de veranderingen in de kwaliteit van gezinsrelaties (Mathijssen, Koot, \& Verhulst, 1999). Onderzoek hiernaar zou onze kennis van het longitudinale verband tussen gezinsrelaties en probleemgedrag tijdens de adolescentie verrijken.

\section{Literatuur}

1. Allen, J. P., Moore, C., Kuperminc, G., \& Bell, K. (1998). Attachment and adolescent psychosocial functioning. Child Development, 69, 1406-1419.

2. Armsden, G. C., \& Greenberg, M. T. (1987). The inventory of parent and peer attachment: individual differences and their relationship to psychological well-being in adolescence. Journal of Youth and Adolescence, 16, 427-453.

3. Armsden, G. C., McCauley, E., Greenberg, M. T., Burke, P. M., \& Mitchell, J. R. (1990). Parent and peer attachment in early adolescent depression. Journal of Abnormal Child Psychology, 18, 683-697.

4. Barnas, M. V., Pollina, L., \& Cummings, E. M. (1991). Life-span attachment: Relations between attachment and socioemotional functioning in adult women. Genetic, Social, and General Psychology Monographs, 117, 
175-202.

5. Barnes, G. M., \& Farrell, M. P. (1992). Parental support and control as predictors of adolescent drinking, delinquency, and related problem behaviors. Journal of Marriage and the Family, 54, 763-776.

6. Bartle-Haring, S., \& Gavazzi, S. M. (1996). Multiple views on family data: the sample case of adolescent, maternal, and paternal perspectives on family differentiation levels. Family Process, 35, 457-472.

7. Bowlby, J. (1982). Attachment and loss: vol. 1. Attachment (2nd ed.). New York: Basic Books.

8. Browne, M. W., \& Cudeck, R. (1993). Alternative ways of assessing model fit. In K. A. Bollen, \& J. S. Long (Eds.), Testing structural equation models (pp. 136-162). Newbury Park, CA: Sage.

9. Coleman, J. (1993). Adolescence in a changing world. In S. Jackson \& H. Rodriguez-Tomé (Eds.), Adolescence and its Social Worlds (pp. 251-268). Hove: Erlbaum.

10. Colin, V. L. (1996). Human attachment. New York: McGraw-Hill.

11. Deković, M. (1999). Risk and protective factors in the development of problem behavior during adolescence. Journal of Youth and Adolescence, 28, 667-685.

12. Deković, M., \& Meeus, W. (1997). Peer relations in adolescence: effects of parenting and adolescent's selfconcept. Journal of Adolescence, 20, 163-176.

13. Fan, X., Thompson, B., \& Wang, L., (1999). Effects of sample size, estimation methods, and model specification on structural equation modeling fit indexes. Structural Equation Modeling, 6, 56-83.

14. Farrell, A. D. (1994). Structural equation modeling with longitudinal data: strategies for examining group differences and reciprocal relationships. Journal of Consulting and Clinical Psychology, 62, 477-487.

15. George, C., Kaplan, N., \& Main, M. (1985). The adult attachment interview. Unpublished manuscript. Berkely: University of California.

16. Hamilton, C. E. (2000). Continuity and discontinuity of attachment from infancy through adolescence. Child Development, 71, 690-694.

17. Jöreskog, K. G., \& Sörbom, D. (1993). LISREL 8: structural equation modeling with the SIMPLIS command language. Hillsdale, $\mathrm{NJ}$ : Erlbaum.

18. Kandel, D., \& Davies, M. (1982). Epidemiology of depressive mood in adolescents. Archives of General Psychiatry, 39, 1205-1212.

19. Laible, D. J., Carlo, G., \& Rafaelli, M. (2000). The differential relations of parent and peer attachment to adolescent adjustment. Journal of Youth and Adolescence, 29, 45-59.

20. Lapsley, D. K., Rice, K. G., \& Fitzgerald, D. P. (1990). Adolescent attachment, identity, and adjustment to college: implications for the continuity of adaptation hypothesis. Journal of Counseling and Development, 68, 561-565.

21. Leadbeater, B. J., Kuperminc, G. P. Blatt, S. J., \& Hertzog, C. (1999). A multivariate model of gender differences in adolescents' internalizing and externalizing problems. Developmental Psychology, 35, 12681282.

22. Lopez, F. G., \& Brennan, K. A. (2000). Dynamic processes underlying adult attachment organization: toward an attachment theoretical perspective on the healthy and effective self. Journal of Counseling Psychology, 47, 283-300.

23. Lopez, F. G., \& Gover, M. R. (1993). Self-report measures of parent-adolescent attachment and separationindividuation: a selective review. Journal of Counseling and Development, 71, 560-569.

24. Lyddon, W. J., Bradford, E., \& Nelson, J. P. (1993). Assessing adolescent and adult attachment: a review of current self-report measures. Journal of Counseling and Development, 64, 237-243.

25. Marcus, R. F., \& Betzer, P. D. S. (1996). Attachment and antisocial behavior in early adolescence. Journal of Early Adolescence, 16, 229-248.

26. Marsh, H. W., \& Hocevar, D. (1988). A new, more powerful approach to multitrait-multimethod analyses: application of second-order confirmatory factor analysis. Journal of Applied Psychology, 73, 107-117.

27. Mathijssen, J. J. P., Koot, H. M., \& Verhulst, F. C. (1999). Predicting change in problem behavior from child and family characteristics and stress in referred children and adolescents. Development and Psychopathology, 11, 305-320.

28. Meeus, W. (1992). Kiezen, legitimeren en adolescente identiteit. Groningen: Wolters Noordhoff.

29. Moffitt, T. E. (1993). Adolescence-limited and life-course persistent antisocial behavior: a developmental taxonomy. Psychological Review, 100, 674-701.

30. Raja, S. N., McGee, R., \& Stanton, W. R. (1992). Perceived attachment to parents and peers and psychological well-being in adolescence. Journal of Youth and Adolescence, 21, 471-485.

31. Roberts, R. E., Andrews, J. A., Lewinsohn, P. M., \& Hops, H. (1990). Assessment of depression in 
adolescents using the Center for Epidemiologic Studies Depression Scale. Psychological Assessment, 2, 122-128.

32. Samuolis, J., Layburn, K., \& Schiaffino, K. M. (2001). Identity development and attachment to parents in college students. Journal of Youth and Adolescence, 30, 373-384.

33. Scholte, R. H. J., Vermulst, A. D., \& De Bruyn, E. E. J. (2001). The Nijmegen Problem Behavior List: construction and validation. Presentation at the $6^{\text {th }}$ conference of the European Association of Psychological Assessment, September 2 - 5, Aachen, Germany.

34. Schumacker, R. E., \& Lomax, R. G. (1996). A beginner's guide to structural equation modeling. New Jersey: Erlbaum.

35. Shreeber, L., Hops, H., \& Davis, B. (2001). Family processes in adolescent depression. Clinical Child and Family Psychology Review, 4, 19-35.

36. Steinberg, L. (2001). We know some things. Journal of Research on Adolescence, 11, 1-19.

37. Verhulst, F. C., \& Koot, H. M. (Eds.) (1995). The epidemiology of child and adolescent psychopathology. New York: Oxford University Press.

38. Waters, E., Merrick, S., Treboux, D., Crowell, J., \& Albersheim, L. (2000). Attachment security in infancy and early adulthood: a twenty-year longitudinal study. Child Development, 71, 684-689.

39. Weinfield, N. S., Sroufe, L. A., \& Egeland, B. (2000). Attachment from infancy to early adulthood in a high-risk sample: continuity, discontinuity, and their correlates. Child Development, 71, 695-702.

\section{Copyright 2005, Bohn Stafleu van Loghum, Houten}

